\title{
Whose voices are heard in the news? A study of sources in television coverage of the Scottish independence referendum
}

\author{
Marina Dekavalla and Alenka Jelen-Sanchez
}

University of Stirling

\begin{abstract}
This article explores the prominence of different types of sources in the coverage of the 2014 Scottish independence referendum on BBC Scotland's regional news bulletin. It combines the most commonly used classifications of news sources in the literature and proposes an integrated taxonomy, in which official, unofficial, elite and non-elite sources may take on news shaper or news maker roles. This taxonomy is used to analyse the referendum coverage on BBC's Reporting Scotland in the final month of the campaign. Findings suggest that, despite the presence of many different types of sources, male-dominated political elites were the main focus in the news. We argue that, although the inclusion of some grassroots and citizen sources is encouraging, the coverage more broadly manifests a liberal democratic logic whereby the media represent the views of politicians and political organisations to the public, whose role is to make an informed choice between them with comparatively limited opportunities to participate in the mediated political debate.
\end{abstract}

Keywords: Media sources, independence referendum, television, Scotland.

\section{Introduction}

The 2014 Scottish independence referendum was arguably one of the biggest political events in Europe that year. Scottish voters were called to decide whether their nation would remain a part of the UK or become an independent country. Eventually $55 \%$ of the electorate decided that Scotland should stay in the UK, but the campaign will primarily be remembered for the unprecedented engagement of citizens in the process in terms of voting $(84.6 \%$ of the 
registered electorate voted, the highest turnout in any UK election or referendum), participating in grassroots politics and reversing a long-standing trend of political disengagement (Cramb, 2015).

Much of this grassroots participation took place on social media, widely seen as having provided a platform for voices not normally heard on mainstream news. Despite this, mainstream 'old' media remained central in setting the parameters of the official political debate (Law, 2015) and television, in particular, maintained its position as the most used media platform in the UK. In 2014, $92 \%$ of UK adults reported watching television almost every day (Ofcom, 2015) and television remained the most used source for news (Reuters Institute for the Study of Journalism, 2015). Despite the gradual transformation of the media landscape, in the period we study 'traditional media organisations continue to play a pivotal role in British politics' (Chadwick and Stanyer, 2011, p. 216) as primary and credible sources of political information, co-creators of public discourse and the main way for social actors to reach a large audience. Therefore, the space they provide to different voices matters and raises fundamental questions about the nature of participation and representation in (or exclusion from) public democratic debate (Cottle, 2003).

This article thus focuses its attention on television and the range of voices represented in its coverage of the Scottish independence referendum. More specifically, it looks at the coverage of the final month of the campaign on BBC Scotland's early evening regional news bulletin (Reporting Scotland) and explores the access different types of news sources were given to the mediated debate. To analyse their presence in the news, our study proposes a taxonomy of sources, based on a combination and classification of the most commonly accepted typologies in the literature. The traditional categories of official sources (sources with recognized political, organisational or social function), unofficial sources ('ordinary' 
people) and experts (knowledgeable individuals) are discussed in their roles as news shapers or news makers (Soley, 1992) and their status as elite or non-elite (Poler Kovačič, 2004b). This taxonomy is then used to analyse the coverage and findings are contextualised within normative democratic theory regarding how the media may promote democratic inclusion and deliberation.

\section{Definitions and taxonomy of sources}

News sources are individuals who contribute to media content by providing newsworthy information to journalists and, as such, they are an integral part of daily news production routines (Cameron et al., 1997; Laban, 2004). Gans (1979) defines them as 'the actors whom journalists observe or interview, including interviewees who appear on the air or who are quoted [...] in articles, and those who only supply background information or story suggestions' (p.80). Johnson-Cartee (2005) labels them as 'news promoters', namely 'those individuals or groups, who draw attention to occurrences' and promote them into 'public events' (p.183). These conceptualizations cover a diversity of sources and ways of providing information to the media, yet our study only focuses on sources that overtly appear and/or are referenced in the news.

Gans (1979) established an early typology of sources, differentiating between knowns (or already known individuals, such as politicians and government officials) and unknowns (or 'ordinary' people). At about the same time, Hall et al. (1978) talk of accredited sources, who become 'primary definers' in the news (they get the first say in how a news event is interpreted) because of the power accorded to them by their institutional position, their representative status (for elected politicians or representatives of interest groups) or their knowledge and expertise in a certain area. Journalists, according to the same account, prefer these sources because they carry institutional authority and are seen as providing 'objective' 
or at least 'authoritative' statements, which journalists need in order to make their stories credible. As Davis (2003) suggests, "the "primary definer" role of official sources is "structurally determined" by the routine practices and values of journalism' which favour sources with high social status (p.35), while in turn, their regular prominence in news accounts further reinforces their social status and power. 'Secondary definers', according to this account, do not usually enjoy this high status and have a complementary role in media reports.

Other authors make similar distinctions between official (Gans's knowns or Hall et al.'s accredited sources) and unofficial (Gans's unknowns or 'ordinary' citizens) sources or elites and non-elites (Cottle, 1993; Fishman, 1980; Sigal, 1973). Like the distinction between 'primary' and 'secondary definers', these categorisations share a focus on the power imbalance between official and non-official sources in accessing media space, but they do not account for differences within these groups (Manning, 2001, p.140). Not all official sources are equally powerful in getting their perspectives heard, there are often power struggles between official sources in defining an event, primary definitions may be dislodged by other definitions, and powerful sources may lose power over time (Anderson, 2003; Schlesinger, 1990). Similarly, not all non-official sources face the same obstacles in securing media attention (Manning, 2001).

The criticisms cited above challenge the correspondence implied in earlier accounts between primary definer and elite status. Indeed, depending on the situation, elite and nonelite sources may function as either news makers or news shapers (Soley, 1992). News makers are individuals who represent a legitimate focus for the news, because they are protagonists in a newsworthy event or offer the media a story that satisfies their news values; whereas news shapers provide analytical and explanatory background for stories initiated by 
others, help audiences to make sense of the news and lend detachment or legitimacy to stories, without being themselves the focus of the news. News shapers are secondary definers and their role is to help interpret the news. While the distinction between official and unofficial sources is a distinction between source categories, the distinction between news makers and news shapers is one between source functions.

These different classifications and definitions of source categories have provided insightful ways to conceptualise the types of social groups that appear in or shape mediated debate, however using them interchangeably and/or in isolation from each other misses the analytical complexity their combination could offer and can lead to conceptual confusion. This study proposes an integrated taxonomy of news sources, which combines previous definitions and classifications into a single model (figure 1), thus allowing for their insights to be integrated and for finer distinctions to be made. This model forms the basis of our theoretical and empirical discussion and can potentially serve as a starting point for other studies analysing news sources.

\section{Towards an integrated taxonomy of news sources}

The taxonomy we propose brings together previous categories and functions in one consistent model (figure 1), allowing a clearer and more comprehensive understanding of the range of sources and their potential influence on traditional news media which, as explained earlier, are the focus of this paper. A mapping of the influence of these sources on digital media, which are not part of 'old' news organisations, falls outside the scope of this study. In our model, the elite and official status axes define four source categories: elite official, nonelite official, experts and unofficial sources. These are ideal types and may exceptionally intertwine - however in most cases their membership is distinct. Newsmaker and news 
shaper functions may be taken on by any category that can offer the media a newsworthy story, although, other things being equal, official status favours a newsmaker role.

\section{FIGURE 1 HERE}

At this stage, it is important to acknowledge that digital and social media, and particularly Twitter and Facebook, are becoming integral to journalistic practices and daily routines (Cision, 2015). Social media enable citizens, civil society, and political and business elites to bypass traditional media and directly communicate with their key publics and each other (Paulussen and Harder, 2014), but they have also became a newsgathering tool used in mainstream media reporting across different areas, including politics (Ahmad, 2010; Herminda, 2013). However, social media do not form a single category in our taxonomy because this is not a source per se, but a channel of communication that may be used by any of the sources in the taxonomy. Therefore in our subsequent analysis we record references to new media sources (e.g. a quote from Twitter) under the different sources they correspond to (e.g. an ordinary viewer or a politician). These new media references were indeed very few in the period we studied, only two news items on Reporting Scotland included five Twitter posts in their reporting (four from political sources and one from an ordinary viewer).

\section{Elite and non-elite official sources}

Official sources are sources determined by their position (Poler Kovačič, 2004a): elected or appointed public officials, politicians and corporations, representatives of governance institutions or authorities (political, economic, cultural, scientific, religious etc.), representatives of NGOs, societies, associations or civic initiatives. Official sources talk about news events in their capacity as an authorised representative of an organisation: for example, they may be high-ranking politicians or party communications professionals. Official sources may have elite or non-elite status: the former enjoy higher political, 
economic or social power, legitimacy, credibility, social status and communications resources, giving them more potential to influence media content (Cottle, 2003; JohnsonCartee, 2005; Reese et al., 1994). The latter benefit from less public recognition and communications resources by comparison, however, their official status still grants them credibility.

Elite official sources include political and state institutions, official political campaigns, corporate, business and economic organisations, major NGOs, as well as news agencies and other traditional media (radio, newspapers, etc.), from which journalists get information (Poler Kovačič, 2004a; 2004b; Shoemaker and Reese, 1996). These sources are situated at the top of the 'hierarchy of credibility' (Davis, 2003) - in most social systems people with higher rank and status are deemed more credible than people with lower rank and status. Journalists are, therefore, 'inclined to respect a certain source hierarchy in which they ascribe more credibility to elite official sources, such as known experts and representatives of political and business institutions, than to unofficial sources, such as ordinary citizens' (Paulussen and Harder, 2014, p.543).

Amongst elite official sources, political sources in particular represent the most used and influential sources in the media (Davis, 2003; 2010). The attention and privileged access they enjoy is due both to their elite status and power in society (Gans, 1979; Hall et al., 1978; Johnson-Cartee, 2005), but also to the public relations professionals they employ to develop sophisticated strategies to get their messages in the news (Moloney, 2000; McNair, 2011). These professional communicators have established an exchange relationship between political actors and the media where the former provide the latter with information they need to attract audiences, in exchange for visibility and coverage (Quinn, 2012). Media dependence on these 'information subsidies' is encouraged by the dominance of the market 
model in journalism, whereby news organisations seek to remain profitable by having a decreasing number of journalists produce an increasing amount of content (McNair, 2011; Lewis et al., 2008), allowing elite political sources to 'clearly set, frame and build considerable portions of the agenda' (Sallot and Johnson, 2006a, p.152).

Non-elite official sources, including smaller non-profit and non-governmental organisations (charities, voluntary organisations, associations, societies, unions, communities), interest, activist and pressure groups (Davis, 2003; Deacon, 2003) as well as small businesses, enjoy lower status of legitimacy, trustworthiness and credibility than their elite counterparts, which is also reflected in their lower visibility and presence in media discourse (Johnson-Cartee, 2005). However, these non-elites are increasingly challenging the 'hierarchy of credibility' by becoming a legitimate and authoritative source in the news, often with the help of professional communicators (Davis, 2003). As Sallot and Johnson (2006b) emphasise, 'many non-profit organisations would not get coverage for their services if it were not for [public relations] practitioners contacting media and writing impressive and persuasive pitches' (p.84). For non-elite official sources though, this task of securing media space is perhaps more difficult, since journalists do not always actively seek out their perspectives as they do with elites (Anderson, 2003).

The dominance of elite official sources in media discourse led to several studies treating them simply as 'official sources' (Davis, 2003) and considering non-elite official sources as unofficial sources instead (Anderson, 2003). Non-elite official sources, however, still represent sources according to their position, who speak on behalf of their organisation and thus differ significantly from unofficial sources (Anderson, 2003; Poler Kovačič, 2004b). As discussed, both elite and non-elite official sources are highly likely to use professional communications techniques to secure and manage their presence in the media and this places 
them in an advantageous position to become news makers because they actively engage in promoting stories in the news (although success is neither guaranteed nor exclusive to official sources).

\section{Experts}

Although many authors place experts in the same category as official sources, others argue that they should be classified separately, as expertise makes their contribution distinctive (Boyce, 2006). Experts do not represent the views of institutions, like official sources do, yet they enjoy elite status in today's knowledge societies. Experts include academics and scientists, noted observers and scholars, knowledgeable individuals, former government representatives, politicians and other actors, who have specialist knowledge about social and political issues (Johnson-Cartee, 2005). It is this knowledge that gives them elite status and legitimates their position as analysts of the meaning of news events (Boyce, 2006). In addition to their knowledge, experts' media access also depends on their skills in working with the media and their relationships with actors within political communities (Pan and Kosicki, 2001; Reese et al., 1994). Even though they can be supporters of a political cause or former official sources, experts often appear as neutral sources, giving 'objective' and 'impartial' analysis of a situation (Boyce, 2006; Shoemaker and Reese, 1996).

\section{Unofficial sources}

Unofficial sources are not sources with authority, elite status, position or expertise, but rather ordinary people, participants or eyewitnesses in events. The credibility and legitimacy of their voices in the news mostly originate from their involvement in events, personal experience and/or a possibility to influence results of opinion polls, elections or referenda (Pan and Kosicki, 2001; Poler Kovačič, 2004a; 2004b). Laban (2004, p.213) conceptualises them as actors, who appear in the news as 'individuals' with their own views 
and interpretations. Based on Gans's (1979) five categories of unknowns, Shoemaker and Reese (1996) distinguish between protesters, rioters, strikers; victims; violators of the laws and mores; voters, survey respondents and other aggregates; and participants in unusual activities. Especially when they are not part of organised groups, these sources lack power, cultural and communication capital, and are less well placed than official sources to become news makers, or leading actors in the news, except in cases when they become involved in an extraordinary event, in deviant or violent behaviour (van Dijk, 1995).

Lewis et al. (2005) offer an extensive analysis of the conditions in which ordinary citizens appear in mainstream news: they are either interviewed directly (vox populi) or included in more indirect ways, e.g. in reports of opinion polls, yet most commonly they are represented through unsubstantiated inferences about what they think or say. This also applies when journalists reference social media contributions by citizens in their reports. Paulussen and Harder (2014) observe that references to unknown people's contributions on social media are mostly made in collective and anonymous terms, as a way to represent the voice of the public. Their perspectives are, therefore, more often talked about by journalists than voiced by themselves directly, at least in traditional media which are the focus of this paper.

Although there are exceptions to this construction of ordinary citizens (for example when they are part of protest and citizen movements), these representations tend to be relatively few (Lewis et al., 2005). Literature on social movements suggests that they face considerable challenges in overcoming the power differential that privileges elite access to public debate and 'mainstream news media's preference for "official sources"' (Medearis, 2005, p.59). This means that in order to have their perspectives heard, they mainly have to resort to disruptive acts of 'coercion' (Medearis, 2005), creating a crisis through civil 
disobedience, marches, boycotts or strikes. Even then, social movements often struggle with 'the conventions and practices of journalism [...] amplifying both violence and sensationalism' (McCurdy, 2012, p.250), rather than the substance of what they have to say. Although official sources do not get guaranteed media attention either, unofficial sources face additional challenges.

L'Etang (2004) critically observes that increasing dominance of public relations techniques in the public sphere further reduces the communication space for ordinary citizens to express their views and concerns in mainstream media. Clearly this is not the case on social media, which are gradually altering the landscape, diminishing the former monopoly of 'old' news organisations and allowing ordinary citizens a more active role in 'redesigning' politics (Chadwick and Stanyer, 2011). However, mainstream media, particularly television, remained a significant locus of public debate during the referendum studied here (Ofcom, 2015; Reuters Institute for the Study of Journalism, 2015). In a 'hybridised' system of old and new media, old media still command considerable power, large audiences and financial resources (Chadwick and Stanyer, 2011). Therefore, the amount of space they provide to different sources to express their views has direct implications for democratic participation in mediated public debate (Cottle, 2003).

Using our integrated typology discussed above, the research question we seek to address in this article is which of these types of sources were most prominent and whose voices were heard less in BBC Scotland's news coverage of the independence referendum. In what follows, we first provide a very brief background on the Scottish referendum campaign before moving to discuss our methodological approach to our research question. 


\section{The Scottish independence referendum and the campaigns}

The Scottish independence referendum took place on 18 September 2014. The discussions about it in the media started much earlier though, with the Scottish National Party's (SNP) victory in the 2011 Scottish Election (Carrell, 2011). The referendum was a historic moment for Scotland, which had been part of the United Kingdom for more than three centuries, and the first time that the electorate was given the opportunity to decide on the existence of the British union. It was also a historic moment for the SNP, which in the previous years had become the most popular Scottish party. Although it has been suggested that the reasons for its rise, at least until its second electoral victory in 2011 , were more in its perceived competence in administration and leadership than in public support for independence (Devine, 2016), its landslide win in 2011 meant that its cause of holding an independence referendum could materialise.

Yes Scotland, the campaign supporting independence, was launched in May 2012 and Better Together, which supported staying in the UK, just a month later. This referendum campaign was arguably one of the longest political campaigns in the UK. Better Together involved the three biggest UK parties with branches in Scotland: Labour, the Conservatives and the Liberal Democrats. All three had been in government in Westminster or in Scotland, alone or in coalitions, in the past. Although they agreed on their stance against Scottish independence, there were still underlying political differences between the three parties, which represented different positions in the political spectrum and remained opponents contesting for government in London and Scotland. There was, therefore, a perceived need among both broadcasters and the parties themselves to have balance between their individual perspectives. 
Yes Scotland included the SNP, the Scottish Green Party and the Scottish Socialist Party - with the SNP being the biggest party in that campaign and the only one that had ever been in government. In addition to the official campaigns, grassroots groups formed during the campaign (e.g. Women for Independence, Working for Scotland) and they organised parallel communication activities, including public meetings and online media, which mobilised the public and ignited debate.

The two campaigns invested heavily in communications resources. In interviews with Dekavalla, political communicators from both sides revealed that, in the last months before the vote, 6-8 people were working in media relations on each side. Apart from the 'umbrella' campaigns, the political parties participating in each campaign also had their own media relations strategies. Communication teams were in regular contact with broadcasters, providing information, organising events for them to cover, arranging for their representatives to appear in interviews and debates, and alerting channels to public appearances of their leading figures.

The same interviews suggested that, in addition to the media campaign, the strategy of the Yes side was to involve ordinary citizens and local communities from the early stages. This meant asking those who supported independence to persuade others in their communities, their workplace and social circle, and to mobilise support at grassroots level through local groups and public meetings. This is because strategists in the Yes campaign felt that people are more likely to be persuaded by people they know, rather than by mainstream media or politicians, who, according to them, had lost public trust. As a result, part of their media strategy was to have non-politicians speaking for the campaign on television as often as possible. 
Civil society organisations were mostly neutral in the campaign. This is in contrast to the 1997 Scottish devolution referendum, where Scottish civil society 'was crucial in leading the [...] campaign for home rule' (Paterson and Wyn Jones, 1999, p.193). In interviews with Dekavalla, representatives of civil society organisations suggested that they saw their role in the campaign as drawing attention to issues like democratic participation, poverty, welfare, local democracy, which might otherwise not have been key in the debate. In order to promote these issues, they organised events and public meetings, run websites and blogs, sent out press releases, and were occasionally interviewed by the media. They felt that their efforts were successful in attracting media attention, but they also thought that they were not seen as, neither intended to become, central participants in the debate. In their view, the media debate was more open to politicians and those who would give a straightforward answer to the binary question of the referendum, rather than to neutral organisations who would not provide direct answers.

Broadcasting regulations in the UK do not allow television to take political sides and both public service and commercial broadcasters are obliged to provide due impartiality and equal space to different political perspectives (McNair, 2009). Newspapers are allowed to openly express political allegiances, however, only one newspaper in Scotland (Sunday Herald) positioned itself in favour of independence. The others, including indigenous titles and Scottish editions of English papers, were ambivalent or outright against independence.

\section{Method}

In order to establish which sources were present in the news coverage of BBC Scotland, we conducted a source analysis ( $c f$. Reese et al., 1994) of the channel's regional news bulletin Reporting Scotland, which was the most watched daily news programme in 
Scotland (BBC Scotland Management Review, 2013/2014), during the final month of the campaign. By contrast to the UK-wide bulletin BBC News at Six, Reporting Scotland is produced specifically for a Scottish audience, who would be voting in the referendum. The final month represents a significant period, when coverage is expected to peak (de Vreese and Semetko, 2002). With the date of the vote approaching, undecided voters have to reach a decision and the media need to provide information to support the electorate in this process.

Between 18 August and 18 September 2014, Reporting Scotland broadcast 123 news stories about the referendum. Each news story represented a unit of analysis and for each we recorded basic information, such as title, date of broadcast, position in the news programme, and the number of sources featured. These were further coded against a 10-item coding frame: in the first instance, name and affiliation of the sources (if identified) were recorded and the sources were assigned into categorises and subcategories as identified in our integrated taxonomy presented earlier. We measured the frequency of sources' appearance and the amount of airtime dedicated to their views, and recorded how each was included (paraphrased by journalists, through a statement in front of the camera, or a longer interview with a journalist), which side of the independence argument their statement favoured (Yes, No or neutral/unidentifiable position), their gender (male, female or unidentified) and the patterns in which they were used within the story (identified openly or reported generically; used just once or re-used; presented as responding to others or providing new arguments). The data were analysed with SPSS. We used descriptive statistics and tested statistical significance and strength of associations with Pearson's Chi-square test and Phi/Cramer's V coefficient between nominal variables, and t-test and one-way ANOVA between scale and nominal variables. 


\section{Findings and discussion}

The 123 stories we analysed were a total of 14 hours and 8 minutes long, and featured 722 sources, who were given just over 5 hours and 16 minutes in total, with 26 seconds average airtime per source. Each story featured on average 5.9 different sources. Almost half of the sources were paraphrased (48.8\%), which means they had the lowest level of control over how their words were represented. $41.7 \%$ of sources made brief statements on camera, while $9.6 \%$ appeared in longer interviews with a reporter. This allowed them the highest level of control/influence over their representation because, even though they may not have had control over the questions they were asked, their statements appeared in the context in which they were made, rather than contextualised by a journalist or edited into the news piece. The average level of influence (with values 1-paraphrasing, 2-camera statement, 3-interview) was 1.6.

\section{The dominance of elite official sources}

As would be expected from our earlier discussion, elite official sources were by far the most prominent type of source in the coverage. More than half $(60.5 \%)$ of all the sources we identified belong to this category (Table 1 and Figure 2), occupying $71.2 \%$ of the total airtime given to all sources (with average $\mu=31$ seconds per source) (Figure 3). This trend, as discussed in more detail in previous sections, has been previously attributed to a range of factors, from journalistic routines that see official elite sources as more credible (Cottle, 2003; Hall et al., 1978; Reese et al., 1994) to the increased professionalisation of public relations and its extensive penetration in most elite organisations and particularly in political parties and campaigns (Froehlich and Rüdiger, 2006; McNair, 2011; Quinn, 2012). Indeed, the great majority of the elite sources we found were representatives of the official Yes and No campaigns and of the political parties, as well as the Scottish and UK Governments. Political sources amounted to $77.6 \%$ of elite official sources and almost half $(47.0 \%)$ of all 
the sources we identified. Business sources accounted for $14.4 \%$ of elite sources, while other subcategories (media, celebrities and prominent figures) had marginal presence. Although elite officials dominated the coverage in terms of both frequency and airtime, they were not allowed the most control in how their views were represented: more than half $(57.2 \%)$ of them were paraphrased, followed by just over one third $(35.5 \%)$ making single camera statements and a small proportion of longer interviews (7.3\%) with a mean influence slightly below the average $(\mu=1.5)$.

The second most prominent category of sources in the coverage was unofficial sources, which made up $19.8 \%$ of the total number of sources (table 1, figure 2). Despite their non-elite status, unofficial sources claimed a significant presence in the Reporting Scotland coverage. This, however, did not entail equal media space to voice their views as they had only $8.5 \%$ of the total airtime (with significantly lower average than other categories at $\mu=$ 11 seconds) given to sources, significantly less than elite and slightly less than non-elite official sources (Figure 3). The vast majority of unofficial sources $(79.7 \%)$ were ordinary citizens, who in more than two thirds of cases appeared in front of the camera giving an individual statement or were interviewed by a reporter. The second most common way of representing citizens' views was through public opinion polls (12.6\% of unofficial sources), while other categories had marginal presence. Although the time they were given was relatively short, unofficial sources were allowed to represent their views in their own words $(\mu=1.8)$, more often than elite official sources. This to an extent contradicts suggestions that ordinary citizens' views are more often talked about by journalists than voiced by themselves in the media (Lewis et al., 2005; Paulussen and Harder, 2014). However, in this case, the role of ordinary citizens in referendum news was primarily to lend authenticity to reports in their function as voters, and perhaps for this reason they were shown speaking on camera more often. 
Non-elite official sources were the third most prominent category ( $9.8 \%$ of sources) in terms of frequency (table 1, figure 2) and second most prominent in terms of airtime $(11.3 \%$; average $\mu=30$ seconds per source) (figure 3). Grassroots campaigners and organisations were the most dominant group among them (64.8\% of non-elite official sources), followed by small businesses $(18.3 \%)$ and non-profit organisations $(9.9 \%)$. Similarly to unofficial sources, non-elite officials had relatively high control over how their views were presented $(\mu$ = 1.9). Despite their relative success in getting coverage, non-elite officials did not challenge the 'hierarchy of credibility' as much as would be expected considering the high involvement of grassroots campaigns in the referendum: their non-elite status still meant that they were significantly less represented in the news than their elite counterparts.

Elite status in this case was reinforced by the designation of the lead campaign groups representing the two sides of the argument by the Electoral Commission: although many groups officially campaigned for and against independence, Yes Scotland and Better Together were selected through a formal process as the head campaigns (Electoral Commission, 2014). Both these campaigns were made up of actors who were already elite - major political parties, senior politicians and prominent public figures. The Electoral Commission's 'stamp' lent them additional elite status, credibility, and even more media attention, which grassroots groups did not enjoy to the same degree.

Experts were somewhat surprisingly the least frequently used type of source in our taxonomy $(5.7 \%$ of all sources with $6.8 \%$ of airtime, yet had the highest average time to express their views $\mu=32$ seconds). In most cases they appeared in front of the camera themselves $(\mu=1.9)$ rather than were paraphrased. In more than two thirds of cases, experts were academics, followed by specialists/analysts/observers and former elite officials.

\section{TABLE 1 HERE}


In general, the more elite the source, the more airtime was allocated to them (association between source category and average airtime was statistically significant, $p=$ 0.004). This was not the case though with the control they were allowed over the presentation of their views, with elite officials shown speaking on camera less than other categories.

A very small proportion of sources we identified (1.8\%) were unnamed or confidential (table 1, figure 2). Their identity was concealed with generalizations, such as 'according to well informed sources', 'it is believed', etc. Any social actor can act as a confidential source and, although their anonymity obscures their ideological position, goals and motives, these 'faceless' sources are an essential part of news production and a precondition for the free flow of information in modern democracies (Johnson-Cartee, 2005).

\section{FIGURE 2 HERE}

FIGURE 3 HERE

It has often been argued (Gamson, 2001; Lewis et al., 2005) that in order to promote a more active citizenry and more participation of the public in common affairs, the media need to include ordinary citizen voices talking about matters of public concern. Our findings suggest that non-elite sources had noticeable presence in the news coverage of the Scottish referendum. Taken together, non-elite sources accounted for $29.6 \%$ of all sources, occupied $19.8 \%$ of airtime, and tended to present their views in their own words more often than elite officials, which is more than would be expected based on research in other contexts (Bennett et al., 2004; Feree et al., 2002). In the case of the Scottish referendum though, this is consistent with the high level of involvement and engagement of the public and grassroots groups with the political process (Cramb, 2015), which seems to be reflected in the BBC's account. Even so, elite sources were more than twice as prominent (66.2\% of the sources) 
and were given almost four times more airtime (78.1\%), suggesting that no matter how involved non-elites were in the political process, elites (and especially politicians) remained dominant by comparison. As will be discussed later in the article, this dominance of elites in political coverage is widely seen as contributing to the reproduction of a liberal perception of politics as the domain of politicians (Feree et al., 2002; Lewis et al., 2005) and is consistent with findings from previous studies of political coverage in Scottish media (Crawford, 2009; Dekavalla, 2012).

\section{Balance between Yes and No sources}

Balance between the perspectives of sources supporting the two sides of the referendum argument seemed to be a significant consideration. We found $37.3 \%$ of all sources favouring a Yes vote and $37.5 \%$ for a No vote, while the remaining quarter were neutral (Figure 4). Broadcasting regulations require television news to provide due impartiality (McNair, 2009), which has traditionally been interpreted by broadcasters as an opportunity for all participants to express their viewpoints. Understood in this sense ${ }^{\mathrm{i}}$, it is clear that the news programme we examined adhered to these requirements in terms of frequency of appearance and (albeit slightly less) in terms of airtime given to each side. No sources received $42.1 \%$ of the time dedicated to all sources, while Yes received $40.4 \%$, with the rest of the time devoted to neutral sources.

\section{FIGURE 4}

With just a quarter of all sources being neutral, the findings here confirm the suggestion made by civil society actors, and discussed earlier in this article, that the media debate during the referendum was more open to sources who would clearly position themselves with one of the two sides, rather than those who did not provide a straightforward answer to the referendum question. The binary character of the referendum is very likely to 
have played a role in this, as the electorate had to choose between only two options. On the other hand, there have also been suggestions that Western media are becoming increasingly polarized in their coverage of politics more broadly and there is a general underrepresentation of moderate voices (McCluskey and Kim, 2012).

Turning to the types of sources that supported each side (Figure 5), we found a statistically significant association $\left(p=0.000 ; \varphi_{c}=0.21\right)$ between source category and advocated side. The No side had more elite official sources endorsing it ( $45.8 \%$ for No, $37.1 \%$ for Yes), particularly elite businesses ( $57.1 \%$ for No, $19.0 \%$ for Yes). The only elite sources that advocated Yes more often than No were celebrities. The Yes side, on the other hand, had significantly higher support from non-elite sources: non-elite official $(47.9 \%$ for Yes, $31.0 \%$ for No) and unofficial sources (35.7\% for Yes, $20.3 \%$ for No) were largely in favour of independence. This is in line with the campaigning strategies of the two sides; as discussed in a previous section, interviews with Dekavalla suggested that the Yes campaign made a decision to be represented by non-politicians in media debates, when possible.

Experts, on the other hand, most often appeared as neutral $(43.9 \%)$, as would be expected from their role as knowledgeable analysts of news events. Another category with a high percentage of neutral sources was unofficial sources $(44.1 \%)$, perhaps reflecting the indecisiveness of voters until the end of the campaign and the close results of opinion polls.

\section{FIGURE 5 HERE}

\section{A male-dominated debate}

The study found great inequality in terms of gender representation. Men were almost three times as prominent as women (42.2\% of all sources versus $16.6 \%)$, while in $41.1 \%$ of cases the gender of the source could not be determined due to generic references. If we 
exclude these generic sources, men represented over $71.8 \%$ of sources (with $80.1 \%$ of airtime) and women $28.2 \%$ of sources (19.9\% of airtime); the difference in airtime between the two genders was statistically significant $(p=0.004)$. Male sources dominated every category, apart from non-elite official sources, where men and women were equally represented. Elite sources (both officials and experts) were particularly male-dominated, with men over four times more commonly used than women, an association that we found to be strongly statistically significant $(p=0.000 ; \varphi=0.31)$.

The finding that men are used as news sources more than women is not unique to our study. A range of studies in different countries and contexts, including in the UK (Ross et al., 2013; Sreberny and Van Zoonen, 2000), have found that women are less likely than men to be used as news sources (see Baitinger, 2015 for a review) which has been attributed both to the gendered nature of journalism and to the underrepresentation of women in the positions and professions that produce newsworthy guests' (Baitinger, 2015, p. 580). Indeed politicians and experts tend to be male-dominated social groups, but even so, women remain underrepresented in the news relative to their actual numbers in these professions (Ross et al., 2013). In the news coverage studied here, women seem underrepresented even among ordinary citizens (although to a lesser extent than within other categories) - our unofficial sources category included $54.8 \%$ men and $45.2 \%$ women. Within the wider context of several studies finding a similar 'gender bias' in news coverage, this has significant implications for questions of democratic gender representation in the media (Ross et al., 2013).

Men were more often No (43.0\%) than Yes supporters (36.1\%), while women were more often for Yes $(38.3 \%)$ rather than No (31.7\%). Women also appeared neutral more often $(30 \%)$ than men $(21 \%)$. The association between gender and side is not statistically 
significant $(p=0.054)$ though. Taking gender, category and side into account (Table 2), by far the most utilised sources were male elites advocating a No position.

\section{TABLE 2 HERE}

\section{A polarised debate between political elites}

In order to measure the degree of dialogue between different types of sources, we recorded whether each source was presented as responding to something said by others or introducing a new argument. We found that there was very little dialogue between sources, or engagement with what each other had to say: $69.9 \%$ of all sources introduced new arguments but did not respond to anyone else's. This finding confirms previous research in Scotland and elsewhere that has found little deliberation and engagement between actors in the news (Crawford, 2009; Feree et al., 2002). This is significant because engagement with opponent arguments is a key requirement for a well-functioning public sphere (Bennett et al., 2004) when sources just present their own views but fail to address each other's perspectives, they do not facilitate democratic deliberation. Although the tendency not to respond to others' arguments was consistent across categories, the highest level of engagement and dialogue was found among elite sources $(38.0 \%$ of elite officials and $34.1 \%$ of experts responded to previously expressed views). Non-elite official and unofficial sources were the least involved in responding to others (both just under 15\%). This association was statistically significant ( $p$ $=0.000 ; \varphi=0.23)$, lending support to the argument that different social strata are rarely presented as engaging in dialogue with each other in news reports (Bennett et al., 2004).

Yes and No sources were far more likely to engage in dialogue than neutral sources. While one third of Yes and No sources responded to already expressed views (usually coming from the other side), neutral sources in their majority (86.3\%) introduced new views with this difference being statistically significant $(p=0.000 ; \varphi=0.21)$. The discussion was, 
therefore, polarised between the Yes and No sides, while neutral sources appeared as an additional voice, detached from the conversation.

\section{Conclusion}

In mass democracies where face-to-face deliberation among all their members is not practically possible, the media represent the main platforms for opinion formation and decision making through public discussion and argumentation (Elster, 1998). As suggested earlier, although digital platforms challenge the monopoly of mainstream media in this respect, the latter still maintain a central role in this process. Who is represented, who is absent, whose voices predominate and whose are marginal in mainstream media debate therefore remain fundamental concerns in democratic theory and public debate alike (Cottle, 2003). The taxonomy of media sources we have proposed in this article allows a more nuanced account of who acts as a source in the news by integrating previous categorisations while distinguishing between types of sources that other taxonomies often classify together (for instance, elite versus non-elite official; non-elite official versus unofficial; elite official versus experts).

In our analysis of the coverage of the 2014 Scottish referendum, specifically, the taxonomy highlighted differences between elite and non-elite official sources in their level of access to the debate, with the former clearly dominating news reports and the latter lagging behind even unofficial sources. By contrast we found that, despite being elite, experts did not have a very prominent position in the coverage. Our analysis, therefore, suggests that the relationship between the status of a source category as elite or official and the frequency with which this type of source appears in the news is not always straightforward. 
Even though the case studied here generally confirmed the well-established journalistic preference for 'credible' elite institutional sources over ordinary citizens, the latter appeared more often than non-elite official organisations or experts, and lent the coverage the 'authenticity' of their voices. This authenticity was important when reporting on a political event that generated so much engagement among the electorate, and it might potentially have helped to generate more. Lewis et al. (2005) argue that the media can contribute to an engaged citizenry by providing audiences with examples of engaged citizens in their coverage. In our study, Reporting Scotland did provide several examples of voters discussing the referendum in their own voice, although the length of time they were offered to speak was less than that given to more elite and official sources.

In general, whether a source category was elite or non-elite seemed to have a more straightforward relationship with the amount of airtime its members enjoyed, rather than with frequency of inclusion. Our findings suggest that elite sources consistently got more airtime than non-elite sources. This distinction between the amount of airtime and frequency of appearance of elite/non-elite and official/unofficial sources in the news is worth further investigation in research on other types of news events.

Reporting Scotland provided equal space for both the Yes and No sides to express their views. The composition of sources speaking for the two sides was different though: nonelite official, unofficial and expert sources, in this order, were more likely to advocate a Yes position, while the No side had notably higher support amongst elite official sources.

Overall, our finding that elite official sources, particularly male politicians, were the most dominant sources overall in terms of frequency and airtime, agrees with trends established in the literature for several decades: elite political sources are the key news makers in major political events and men are far more prominent than women. The 
prominence of elite politicians in the mediated debate is consistent with liberal democratic ideals. These suggest that the role of citizens in democracy is to elect their preferred representatives to deal with public issues and the role of the media is to represent the views of politicians to the public, so that they can make an informed choice between what they propose (Hackett, 2005; Feree et al., 2002).

However, the unprecedented engagement of ordinary citizens and grassroots campaign groups in the democratic process made the Scottish independence referendum distinctive from other referenda and elections in the UK (Law, 2015). It also offered a rare opportunity for a mediated construction of citizenry as envisaged by participatory democratic theorists who argue that citizen empowerment and participation in public affairs can be 'learnt' by seeing examples of such engagement in the news (Gamson, 2001; Lewis et al., 2005). This opportunity was taken only to a certain extent by the news programme we studied.

As Parkinson (2005, p.178) suggests, 'in order to get their story told rather than someone else's, [sources] must jockey hard for the media's attention, largely on the basis of news values and salience to organizationally significant audiences'. Traditional media in Scotland and in the UK operate according to a liberal system (Hallin and Mancini, 2004) and a liberalist view of politics as 'intra-elite debate' (Hackett, 2005, p.86) with an overall tendency to privilege men (Ross et al., 2013) appears to be ingrained in both news values and newsgathering routines. Although there is space, especially during such an inclusive and engaging political event as was the Scottish referendum, for ordinary citizens and grassroots groups to challenge the established 'hierarchy of credibility', overturning the principle that sees politics as the job of politicians and men remains a difficult task.

WORD COUNT: 7,614 DATE: 12/08/2016 
Acknowledgement: Marina Dekavalla holds an ESRC Future Research Leaders award for the project "Television framing of the 2014 Scottish independence referendum" which is supported by the Economic and Social Research Council (grant number ES/L010062/1).

i During the campaign the BBC was accused by Yes supporters of bias on different grounds, but a discussion of definitions of bias is beyond the scope of this article. In terms of sources' access to mediated space, which is the focus of our analysis here, the data we studied show equal distribution of Yes and No sources. 


\section{References}

Ahmad, A. N. (2010) Is Twitter a useful tool for journalists? Journal of Media Practice 11(2): 145-155.

Anderson, A. (2003) Environmental activism and news media. In: S. Cottle (ed.) News, Public Relations and Power. London, Thousand Oaks, New Delhi: Sage, pp. 117-132.

BBC Scotland. (2014) BBC Scotland Management Review 2013/2014, http://downloads.bbc.co.uk/annualreport/pdf/2013-14/BBC_NR_MR_Scotland_201314_AP. pdf, accessed 25 February 2016.

Baitinger, G. (2015) Meet the press or meet the men? Examining women's presence in American news media. Political Research Quarterly 68(3): 579-592.

Bennett, W.L., Pickard, V., Iozzi, D., Schroeder, C., Lagos, T. and Caswell, C. (2004) Managing the public sphere: Journalistic construction of the great globalization debate. Journal of Communication 54(3): 437-455.

Boyce, T. (2006) Journalism and expertise. Journalism Studies 7(6): 889-906.

Cameron, G. T., Sallot, L. M. and Curtin, P. A. (1997) Public relations and the production of news: A critical review and a theoretical framework. In: B. Burleson (ed.) Communication Yearbook 20. Thousand Oaks, CA: Sage, pp. 111-155.

Carrell, S. (2011) Stunning SNP election victory throws spotlight on Scottish independence. The Guardian, 6 May, http://www.theguardian.com/politics/2011/may/06/snp-electionvictory-scottish-independence, accessed 25 February 2016. 
Chadwick, A. and Stanyer, J. (2011) The changing news media environment. In: R.

Heffernan, P. Cowley and C. Hay (eds.) Developments in British Politics, volume 9.

Basingstoke: Palgrave Macmillan, pp. 215-237.

Cision (2015) Global social journalism study, http://www.cision.com/us/resources/whitepapers/2015-global-social-journalism-study/?clid=whitepaper-ty, accessed 4 March 2016.

Cottle, S. (1993) TV News, Urban Conflict and the Inner City. Leicester: Leicester University Press.

Cottle, S. (2003) News, public relations and power: Mapping the field. In: S. Cottle (ed.) News, Public Relations and Power. London, Thousand Oaks, New Delhi: Sage, pp. 3-24.

Cramb, A. (2015) Why are Scots still more likely to vote than the rest of the country? The Telegraph, 25 May, http://www.telegraph.co.uk/news/general-election-2015/11492445/Whyare-Scots-still-more-likely-to-vote-than-the-rest-of-the-country.html, accessed 25 February 2016.

Crawford, E. (2009) A new sort of democracy? The opinion pages in the Scottish daily quality press. Journalism 10(4): 451-472.

Davis, A. (2003) Public relations and news sources. In: S. Cottle (ed.) News, Public Relations and Power. London, Thousand Oaks, New Delhi: Sage, pp. 27-42.

Davis, A. (2010) Political Communication and Social Theory. Oxon, New York: Routledge.

Deacon, D. (2003) Non-governmental organisations and the media. In: S. Cottle (ed.) News, Public Relations and Power. London, Thousand Oaks, New Delhi: Sage, pp. 99-115. 
Dekavalla, M. (2012) Evaluating newspaper performance in the public sphere: Press accounts of Westminster elections in Scotland and in England in the early post-devolution period. Journalism 13(3): 320-339.

Devine, T. (2016) Independence or Union: Scotland's Past and Scotland's Present. London: Penguin.

de Vreese, C. and Semetko, H. (2002) Cynical and engaged: Strategic campaign coverage, public opinion, and mobilization in a referendum. Communication Research 29(6): 615-641.

Electoral Commission (2014). The designation process, Referendum on independence for Scotland 2014, http://www.electoralcommission.org.uk/ data/assets/pdf_file/0010/164395/sp-risdesignation.pdf, accessed 25 February 2016.

Elster, J. (1998) Introduction. In: Elster, J. (ed.) Deliberative Democracy. New York: Cambridge University Press.

Feree, M.M., Gamson, W.A. Gerhards, J. and Rucht, D. (2002) Shaping Abortion Discourse: Democracy and the Public Sphere in Germany and the United States. New York: Cambridge University Press.

Fishman, M. (1980) Manufacturing the News. Austin: University of Texas Press.

Froehlich, R. and Rüdiger, B. (2006) Framing political public relations: Measuring success of political communication strategies in Germany. Public Relations Review 32: 18-25.

Gamson, W.A. (2001) Promoting political engagement. In: W.L. Bennett and R. M. Entman (eds.) Mediated Politics: Communication and the Future of Democracy. New York: Cambridge University Press. 
Gans, H. J. (1979) Deciding What's News: A study of CBS Evening News, NBC Nightly News, Newsweek and Time. New York: Pantheon.

Hackett, R. A. (2005) Is there a democratic deficit in US and UK journalism? In: S. Allan (ed.) Journalism: Critical Issues. Maidenhead: McGraw-Hill, pp. 85-97.

Hall, S., Critcher, T., Jefferson, T., Clarke, J. and Roberts, B. (1978) Policing the Crisis: Mugging, the State and Law and Order. Basingstoke: Macmillan Press.

Hallin, D. and Mancini, P. (2004) Comparing Media Systems: Three Models of Media and Politics. Cambridge: Cambridge University Press.

Johnson-Cartee, K. S. (2005) News Narratives and News Framing: Constructing Political Reality. Lanham: Rowman and Littlefield.

Laban, V. (2007) Televizijsko novinarstvo: Hibridizacija žanrov in stilov. Ljubljana: FDV.

Law, A. (2015) Mediating the Scottish independence debate. Media Education Journal 56: 37.

L'Etang, J. (2004) Public Relations in Britain: A History of Professional Practice in the $20^{\text {th }}$ Century. Mahwah, New Jersey: Lawrence Erlbaum Associates.

Lewis, J., Inthorn, A. and Wahl-Jorgensen, K. (2005) Citizens or Consumers? The Media and the Decline of Political Participation. Maidenhead: Open University Press.

Lewis, J., Williams, A. and Franklin, B. (2008) A compromised fourth estate? UK news journalism, public relations and news sources. Journalism Studies 9(1): 1-20.

Manning, P. (2001) News and News Sources. London: Sage. 
McCurdy, P. (2012) Social movements, protest and mainstream media. Sociology Compass 6(3): 244-255.

McCluskey, M. and Kim, Y.M. (2012) Moderatism or polarisation? Representation of advocacy groups' ideology in newspapers. Journalism and Mass Communication Quarterly 89(4): 565-584.

McNair, B. (2009) News and Journalism in the UK. Abingdon: Routledge.

McNair, B. (2011) An Introduction to Political Communication. $5^{\text {th }}$ edition. London, New York: Routledge.

Medearis, J. (2005) Social movements and deliberative democratic theory. British Journal of Political Science 35(1): 53-75.

Moloney, K. (2000) The rise and fall of spin: Changes of fashion in the presentation of UK politics. Journal of Public Affairs 1(2): 124-135.

Ofcom (2015) Adults' media use and attitudes. Report May 2015. Available from http://stakeholders.ofcom.org.uk/market-data-research/other/research-publications/adults/ media-lit-10years/, accessed 25 February 2016.

Quinn, T. (2012) Spin doctors and political news management: A rational-choice 'exchange' analysis. British Politics 7(3): 272-300.

Pan, Z. and Kosicki, G. M. (2001) Framing as strategic action in public deliberation. In: S. D. Reese, O. H. Gandy, Jr. and A. E. Grant (eds.) Framing Public Life: Perspectives on Media and Our Understanding of the Social World. Mahwah, NJ, London: Lawrence Erlbaum Associates, pp. 35-65. 
Parkinson, J. (2005) Rickety bridges: Using the media in deliberative democracy. British Journal of Political Science 36(1): 175-183.

Paterson, L. and Wyn Jones, R. (1999) Does civil society drive constitutional change? In: B. Taylor and K. Thomson (eds.) Scotland and Wales: Nations again? Cardiff: University of Wales Press, pp.169-197.

Paulussen. S. and Harder, R. A. (2014) Social Media References in Newspapers. Journalism Practice 8(5): 542-551.

Poler Kovačič, M. (2004a) Novinarska (iz)virnost: Novinarji in njihovi viri v sodobni slovenski družbi. Ljubljana: FDV.

Poler Kovačič, M. (2004b) Novinarska rutina in (pre)moč uradnih virov informacij. Teorija in praksa 41(3-4): 690-702.

Reese, S. D., Grant, A. and Danielian, L. H. (1994) The structure of news sources on television: A network analysis of 'CBS News,' 'Nightline,' 'MacNeil/Lehrer,' and 'This Week with David Brinkley'. Journal of Communication 44(2): 84-107.

Reuters Institute for the Study of Journalism. (2015) Sources of News. Digital News Report 2015, http://www.digitalnewsreport.org/survey/2015/sources-of-news-2015/, accessed 4 March 2016.

Ross, K. Evans, E., Harrison, L., Shears, M. and Wadia, K. (2013). The Gender of News and News of Gender: A Study of Sex, Politics, and Press Coverage of the 2010 British General Election. The International Journal of Press/Politics 18(1): 3-20. 
Sallot, L. M. and Johnson, E. A. (2006a) Investigating relationships between journalists and public relations practitioners: Working together to set, frame and build the public agenda, 1991-2004. Public Relations Review 32: 151-159.

Sallot, L. M. and Johnson, E. A. (2006b) To contact ... or not? Investigating journalists' assessments of public relations subsidies and contact preferences. Public Relations Review 32: $83-86$.

Schlesinger, P. (1990) Rethinking the sociology of journalism: Source strategies and the limits of media-centrism. In: M. Ferguson (ed.) Public Communication: Future Directions for Media Research. London: Sage, pp. 61-83.

Shoemaker, P. J. and Reese, S. D. (1996) Mediating the Message: Theories of Influences on Mass Media Content. New York: Longman.

Sigal, L. V. (1973) Reporters and Officials. Lexington: D.C. Heath and Company.

Soley, L. C. (1992) The News Shapers: The Sources Who Explain the News. New York: Praeger.

Sreberny, A. and Van Zoonen, L. (eds.) (2000). Gender, Politics and Communication. New York: Hampton Press.

van Dijk, T. A. (1995) Power and the news media. In: D. L. Paletz (ed.) Political Communication in Action: States, Institutions, Movements, Audiences. Cresskill, NJ: Hampton Press, pp. 9-36. 
Figure 1. Taxonomy model of news sources

\begin{tabular}{|c|c|c|c|}
\hline \multirow{3}{*}{ 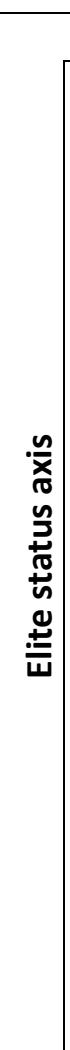 } & \multicolumn{3}{|c|}{ Official status axis } \\
\hline & 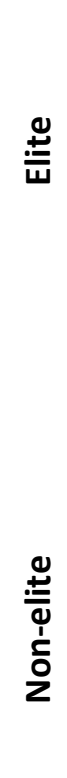 & $\begin{array}{l}\text { Official sources } \\
\text { Political and state institutions } \\
\text { Corporations and business organisations } \\
\text { Celebrities and famous personalities } \\
\text { Major NGOs } \\
\text { Press agencies and other media }\end{array}$ & $\begin{array}{l}\text { Experts } \\
\text { Scientists and academics } \\
\text { Specialists, professionals, analysts and } \\
\text { observers } \\
\text { Former politicians, public officials and } \\
\text { corporate executives }\end{array}$ \\
\hline & & News makers & News shapers \\
\hline
\end{tabular}


Table 1. Frequency of categories and subcategories of sources in Reporting Scotland

\begin{tabular}{|lccc|}
\hline Source & N & \% within category & \% overall \\
\hline Elite official & 437 & 100 & 60.5 \\
\hline Politics & 339 & 77.6 & 47.0 \\
\hline Business & 63 & 14.4 & 8.7 \\
\hline Media & 13 & 3.0 & 1.8 \\
\hline Celebrity & 20 & 4.6 & 2.8 \\
\hline Other & 2 & 0.5 & 0.3 \\
\hline Non-elite official & 71 & 100 & 9.8 \\
\hline Campaigners, activists, movements & 46 & 64.8 & 6.4 \\
\hline Small business & 13 & 18.3 & 1.8 \\
\hline Unions & 5 & 7.0 & 0.7 \\
\hline Non-profit & 7 & 9.9 & 1.0 \\
\hline Expert & 41 & 100 & 5.7 \\
\hline Academic & 28 & 68.3 & 3.9 \\
\hline Specialist & 7 & 17.1 & 1.0 \\
\hline Ex-officio & 4 & 9.8 & 0.6 \\
\hline Other & 2 & 4.9 & 0.3 \\
\hline Unofficial & 143 & 100 & 19.8 \\
\hline Vox populi & 114 & 79.7 & 15.8 \\
\hline Polls & 18 & 12.6 & 2.5 \\
\hline Protesters & 5 & 3.5 & 0.7 \\
\hline Participants & 6 & 4.2 & 0.8 \\
\hline Confidential & 13 & 100 & 1.8 \\
\hline Unaccounted & 17 & 100 & 2.4 \\
\hline
\end{tabular}


Figure 2. Different types of sources used in Reporting Scotland (\%)

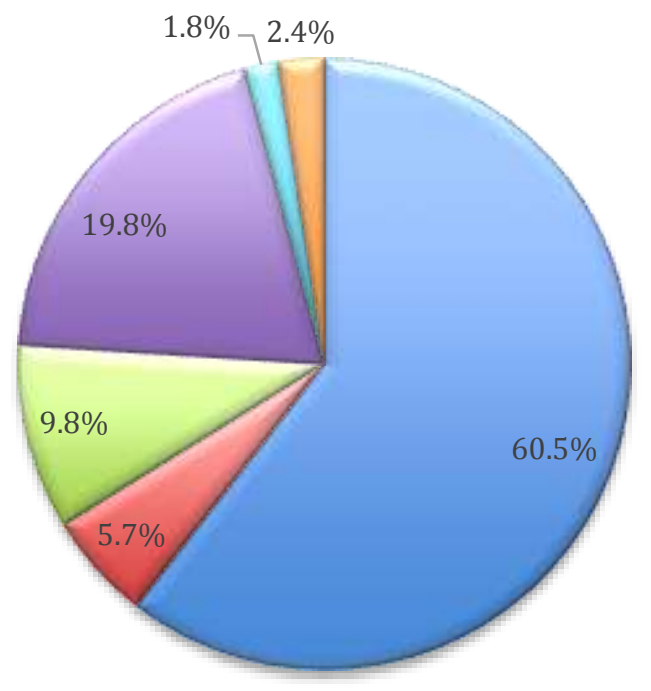

घElite official

$\square$ Experts

$\square$ Non-elite official

๑Unofficial

$\square$ Confidential

Ⓤnaccounted 
Figure 3. Airtime allocated to different types of sources (\%)

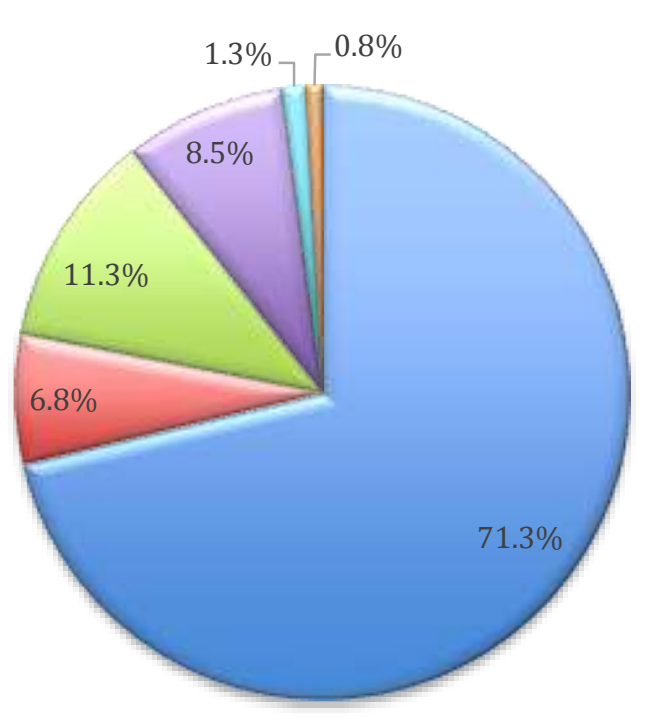

Elite official $\square$ Experts

$\square$ Non-elite official Unofficial

$\square$ Confidential

Ⓤnaccounted 
Figure 4. Yes, No and neutral sources represented in Reporting Scotland (\%)

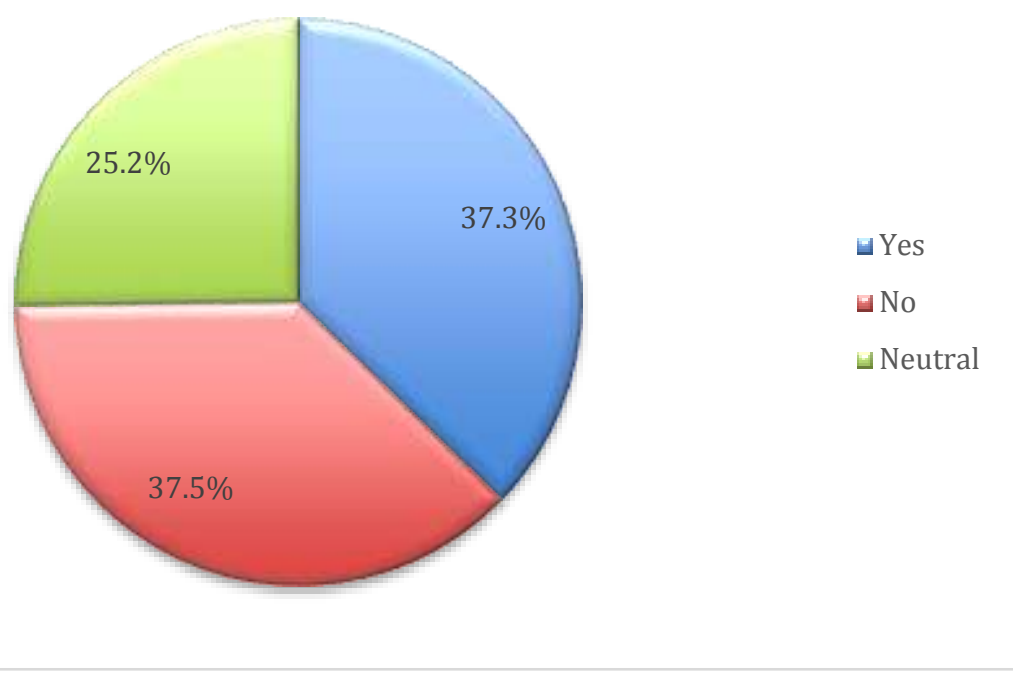


Figure 5. Source categories and sides taken in the referendum debate (\%)

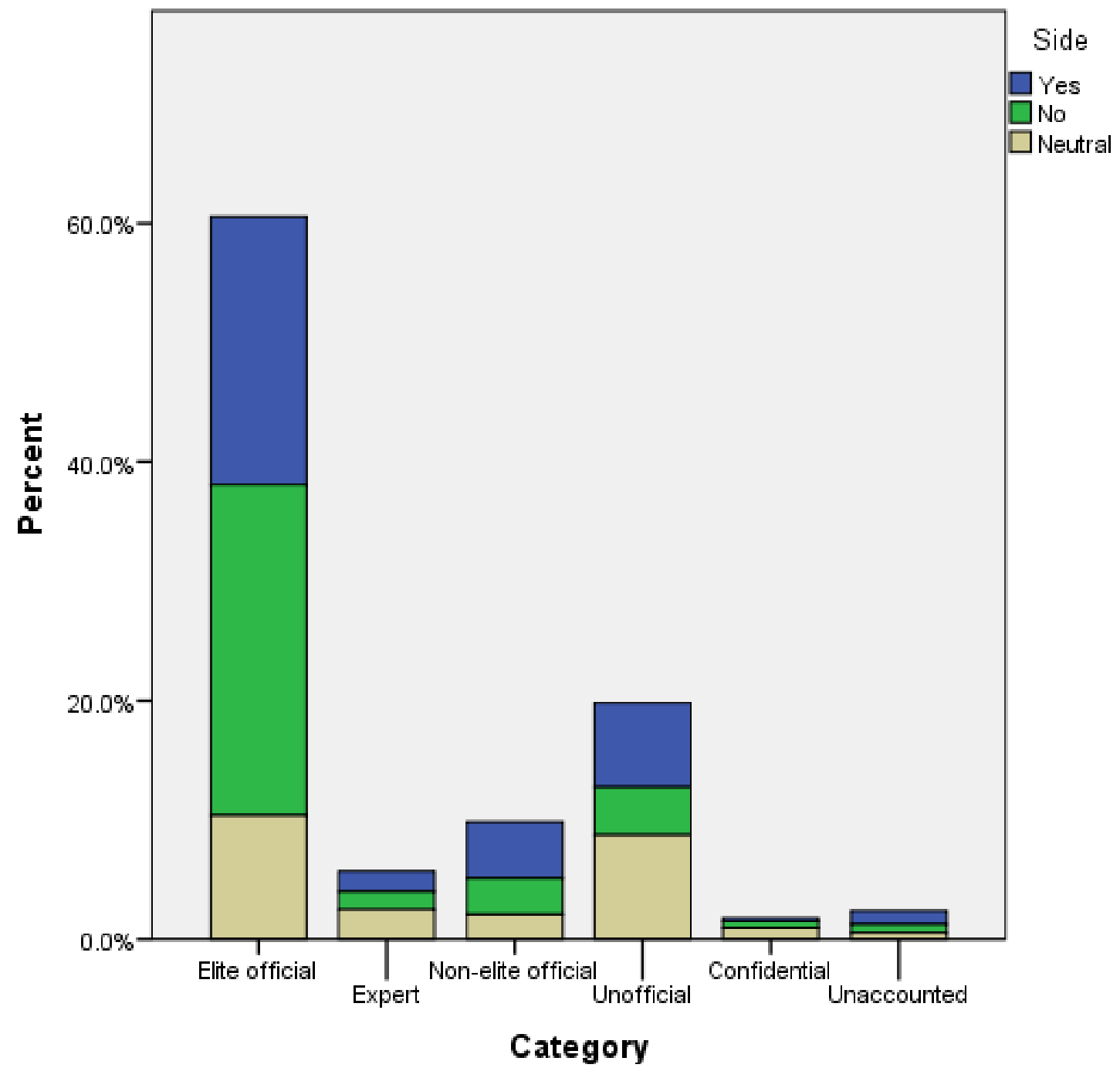


Table 2. Sources $(\mathrm{N})$ according to category, gender and side

\begin{tabular}{|lllllllll|} 
& \multicolumn{2}{c}{ Yes } & \multicolumn{2}{c}{ No } & \multicolumn{2}{c}{ Neutral } & Total \\
\hline & \multicolumn{2}{c}{ Male } & Female & Male & Female & Male & Female \\
\hline Elite official & 66 & 22 & 104 & 9 & 26 & 11 & 238 \\
\hline Expert & 9 & 1 & 8 & 2 & 10 & 3 & 33 \\
\hline Non-elite official & 12 & 12 & 7 & 11 & 6 & 2 & 50 \\
\hline Unofficial & 23 & 11 & 12 & 16 & 22 & 20 & 104 \\
\hline Total & 110 & 46 & 131 & 38 & 64 & 36 & $425^{*}$
\end{tabular}

*297 sources (41.1\%), whose gender could not be determined due to anonymous and/or generic references in the news items are excluded from this count. 